\title{
Acidic fermentation in the caecum increases absorption of calcium and magnesium in the large intestine of the rat
}

\author{
BY HASSAN YOUNES, CHRISTIAN DEMIGNÉ* AND CHRISTIAN RÉMÉSY \\ Laboratoire des Maladies Métaboliques, INRA de Clermont-Ferrand/Theix, F-63122 \\ Saint-Genès-Champanelle, France
}

(Received 7 September 1994-Revised 12 April 1995-Accepted 18 May 1995)

\begin{abstract}
The effect of fermentation on colonic absorption of $\mathrm{Ca}$ and $\mathrm{Mg}$ was investigated in 8-week-old rats adapted to diets containing either digestible wheat starch (DS diets) or including resistant starch, i.e. $350 \mathrm{~g}$ raw potato starch $/ \mathrm{kg}$ (RS diets). The dietary Ca level of the DS and RS diets was $2.5 \mathrm{or} 7.5 \mathrm{~g} / \mathrm{kg}$. RS diets resulted in enlargements of the caecum together with hypertrophy of the caecal wall. Acidification of the caecal contents by microbial fermentation of RS was influenced by the dietary $\mathrm{Ca}$ level. Very acidic pH conditions and relatively low concentrations of short-chain fatty acids, in the presence of lactic acid fermentation, were observed with the $2.5 \mathrm{~g} \mathrm{Ca} / \mathrm{kg}$ level. Rats fed on RS diets had a higher percentage of soluble $\mathrm{Ca}$ (and inorganic phosphate) in the caecum, particularly of rats adapted to the high Ca level. As a result of the hypertrophy of the caecal wall and of an elevated concentration of soluble Ca, the caecal absorption of Ca was 5-6-fold higher in the RS groups than in the DS groups. The difference between dietary intake and faecal excretion (DI-FE) of Ca was higher in rats fed on RS diets than in those fed on DS diets, when the dietary Ca level was $2.5 \mathrm{~g} / \mathrm{kg}$. With the higher $\mathrm{Ca}$ intake the elevated rate of $\mathrm{Ca}$ absorption from the caecum in RS-fed rats was not paralleled by an enhanced DI-EE difference: this suggests a shift of the Ca absorption towards the large intestine. Feeding RS diets also enhanced $\mathrm{Mg}$ caecal absorption, resulting in a substantially higher DI-FE difference for $\mathbf{M g}$, especially with the $2.5 \mathrm{~g} \mathrm{Ca} / \mathrm{kg}$ diets, because a high $\mathrm{Ca}$ intake tends to inhibit $\mathrm{Mg}$ absorption. The present findings support the view that the large intestine may represent a major site of $\mathrm{Ca}$ (and $\mathbf{M g}$ ) ahsorption when acidic fermentations take place. This process could improve the digestive Ca balance when the dietary $\mathrm{Ca}$ supply is low; when the $\mathrm{Ca}$ supply is affluent, it rather shifts $\mathrm{Ca}$ absorption towards a more distal site of the digestive tract.
\end{abstract}

Calcium: Resistant starch: Caecum: Fermentation: Rat

The effect of large intestinal fermentation on the bioavailability of minerals, especially $\mathrm{Ca}$, is still uncertain. The lumen $\mathrm{pH}$, the caecal surface area and the concentration of organic acids in the large intestine are closely associated with the quantities of fermentable carbohydrates, as well as mineral concentrations (Demigné et al. 1989). Thus, in contrast with the small intestine, it is necessary to take microbial fermentation into account when investigating the mechanisms governing the availability and the possible absorption of minerals by the colon. Dietary fibre or resistant starch (RS) represent a major source of complex carbohydrates for the intestinal microflora in animals or humans (McFarlane \& Cummings, 1991). Carbohydrates that escape digestion in the small intestine are substrates for the formation of short-chain fatty acids (SCFA) in the large intestine, which allows the recovery of part of their energy (Morand et al. 1992). Under certain circumstances, foods rich in complex carbohydrates (for example, wheat bran) may alter the digestive balance of essential minerals, by impairing absorption in the small intestine (Rheinhold et al. 1976; Donagelo \& Eggum, 1986). However, minerals strongly associated with plant cell walls can

\footnotetext{
* For reprints.
} 
be released only by the microbial breakdown of these complex polysaccharides in the large intestine. Thus, it is important to consider the contribution of the colon in the overall absorption of minerals, especially in relation to the major divalent cations. In fact, frequently the apparent absorption of minerals is unchanged by dietary fibre, but fibre may shift the major site of absorption towards the large intestine (Cummings et al. 1979; Demigne et al. 1989). It has been shown that the large intestine is a major site of $\mathbf{M g}$ absorption (Hardwick et al. 1990; Lutz et al. 1991), which is consistent with the fact that $\mathrm{Mg}$ (mainly present in plant foods) becomes fully available after the microbial digestion of fibre. Efficient absorption of $\mathrm{Ca}$ in the rat caecum is possible, but the contribution of the large intestine is still unclear (Petith \& Schedl, 1976; Hylander et al. 1980; Nellans \& Goldsmith, 1981; Schulz et al. 1993).

Thus, it appeared interesting to consider the mechanisms by which fermentation could influence the absorption of $\mathrm{Ca}$ and $\mathrm{Mg}$. Previous work has shown a positive effect of complex carbohydrates and oligosaccharides on $\mathrm{Ca}$ digestibility, probably by improving the solubility of this cation in caecal contents (Levrat et al. 1991 $a, b$; Rémésy et al. 1993). Studies on the interactions between $\mathrm{Ca}$ and fermentation are relevant also because minerals, particularly $\mathrm{Ca}$, are essential to the equilibrium established between the host and the microflora and they have probably a protective effect on the colonic mucosa against cytotoxic agents (Lipkin, 1991). This may reflect the fact that a high dietary Ca intake drastically depresses the solubility of fatty acids as well as that of bile acids in the large intestine (Gorvers \& Van der Meer, 1993).

The present investigation examined the role of fermentation on the distal absorption of divalent cations and the consequences on their digestive balance. The present study also sought to clarify the reciprocal interactions between $\mathrm{Ca}$ absorption in the upper and lower parts of the digestive tract, and the effect of dietary $\mathrm{Ca}$ intake on microbial fermentations in the large intestine.

MATERIALS AND METHODS

Animals and diets

Forty male Wistar rats (IFA-CREDO, L'Arbresle, France) were fed on a commercial pelleted diet (UAR, Villemoisson s/Orge, France) until their body weights reached approximately $200 \mathrm{~g}$ ( 8 weeks). Groups of ten rats were fed for $21 \mathrm{~d}$ on a basal (fibre-free; DS) purified diet, or diets containing $350 \mathrm{~g}$ RS $/ \mathrm{kg}$ (Table 1). RS was a raw potato starch supplied by Louis François, St-Maur, France; about $750 \mathrm{~g} / \mathrm{kg}$ of this starch was amylase (EC 3.2.1.1)-resistant (Andrieux et al. 1989). The animals were housed two per cage (wirebottomed to limit coprophagy) and maintained in temperature-controlled rooms $\left(22^{\circ}\right)$ with the dark period from 20.00 to 08.00 hours. Daily food consumption and body weight were recorded every $3 \mathrm{~d}$ during the first week, then daily during the period of digestive balance determination. Faeces were collected and weighed over four consecutive $24 \mathrm{~h}$ periods for studies on minerals excretion.

\section{Sampling procedures}

The rats were slaughtered just after the dark period (between 08.00 and 09.00 hours). After anaesthesia ( $40 \mathrm{mg}$ sodium pentobarbital $/ \mathrm{kg}$ ), blood samples were taken from the caecal vein $(0.5 \mathrm{ml}$, at a rate of $0.5 \mathrm{ml} / \mathrm{min})$ and then the artery, as described previously (Demigné \& Remesy, 1985). For blood flow measurement, bromosulphophthalein in saline $(5 \mathrm{mmol} / \mathrm{l})$ was infused into a small vein on the internal curvature of the caecum at a rate of $50 \mu \mathrm{l} / \mathrm{min}$ : determination of the marker dilution in the vein draining the whole caecum (without collateral circulation to ileum or colon) was used to calculate the caecal blood flow After blood sampling, the fat present on the caecum was removed and the caecum, complete with contents, was removed and weighed (total caecal weight). Duplicate samples 
Table 1. Composition $(\mathrm{g} / \mathrm{kg})$ of the experimental diets

\begin{tabular}{|c|c|c|c|c|c|}
\hline \multirow[b]{2}{*}{ Ingredients } & \multirow{2}{*}{$\begin{array}{l}\text { Dietary starch ... } \\
\text { Ca level }(\mathrm{g} / \mathrm{kg}) \ldots\end{array}$} & \multicolumn{2}{|c|}{ Digestible } & \multicolumn{2}{|c|}{ Resistant } \\
\hline & & $2 \cdot 5$ & $7 \cdot 5$ & $2 \cdot 5$ & $7 \cdot 5$ \\
\hline Wheat starch & & 742 & 716 & 392 & 376 \\
\hline Crude potato starch & & 0 & 0 & 350 & 350 \\
\hline Casein & & 150 & 150 & 150 & 150 \\
\hline Maize oil & & 50 & 50 & 50 & 50 \\
\hline Mineral mixture* $\ddagger$ & & 40 & 40 & 40 & 40 \\
\hline Vitamin mixture $\downarrow$ & & 10 & 10 & 10 & 10 \\
\hline $\mathrm{CaCO}_{3}$ & & 1.25 & $3 \cdot 75$ & 1.25 & 3.75 \\
\hline $\mathrm{CaHPO}_{4}$ & & 6.8 & $20 \cdot 4$ & 6.8 & $20-4$ \\
\hline
\end{tabular}

* Supplied (mg/kg diet): $\mathrm{KCl} 6 \mathrm{~g}, \mathrm{NaCl} 6 \mathrm{~g}, \mathrm{MgCl}_{2} \cdot 6 \mathrm{H}_{2} \mathrm{O} 6.8 \mathrm{~g}, \mathrm{Fe}_{2} \mathrm{O}_{3} 2 \cdot 5, \mathrm{MnSO}_{4} 125, \mathrm{CuSO}_{4} .7 \mathrm{H}_{2} \mathrm{O} 0.2$, $\mathrm{ZnSO}_{4} .7 \mathrm{H}_{2} \mathrm{O} 100, \mathrm{KI} 0 \cdot 4$. In both groups, $\mathrm{Ca}$ was supplied as $\mathrm{CaCO}_{3}$ and $\mathrm{CaHPO}_{4}$ to have a $\mathrm{Ca}: \mathrm{P}_{1}$ of 1.25 .

† Vitamins supplied $(\mathrm{mg} / \mathrm{kg}$ diet): thiamin 20 , riboflavin 15 , pyridoxine 10 , nicotinamide 100 , calcium pantothenate 70 , folic acid 5, biotin $0 \cdot 3$, cyanocobalamin 0.05 , retinyl palmitate $1 \cdot 5$, DL- $\alpha$-tocopheryl acetate 125 , cholecalciferol $0 \cdot 15$, menadione $1 \cdot 5$, ascorbic acid 50, myo-inositol 100 , choline $1 \cdot 36 \mathrm{~g}$.

¥ Both vitamin and mineral mixes were purchased from UAR (Villemoisson, Epinay-sur-Orge, France).

of caecal contents were placed in $2 \mathrm{ml}$ microfuge tubes and stored immediately at $-20^{\circ}$, then the caecal wall was flushed clean with ice-cold saline, blotted on filter paper and weighed (caecal wall weight). Supernatant fractions of the caecal contents were obtained by centrifuging the microfuge tubes at $20000 \mathrm{~g}$ for $10 \mathrm{~min}$ at $4^{\circ}$.

\section{Analytical procedures}

SCFA were determined by gas-liquid chromatography of portions of supernatant fractions of caecal contents (Demigné et al. 1980). Lactic acid concentrations (L- or D-forms) were measured using the reaction catalysed by the $\mathrm{L}(+)$ or $\mathrm{D}(-)$ dehydrogenases $(E C$ 1.1.1.27 and EC 1.1.1.28 respectively) under conditions described by Gutmann \& Wahlefeld (1974), after treatment of caecal supernatant fractions with 10 vol. $0.4 \mathrm{M}-\mathrm{HClO}_{4} . \mathrm{Mg}, \mathrm{Ca}$ and inorganic phosphate $\left(\mathrm{P}_{\mathrm{i}}\right)$ were determined on the caecal supernatant fractions (soluble) and after mineralization $\left(0.8 \mathrm{M}-\mathrm{HCl}, 12 \mathrm{~h}\right.$ at $\left.800^{\circ}\right)$ of the untreated caecal samples (total). For $\mathrm{Ca}$ and $\mathrm{Mg}$ analysis the resulting residue was extracted with $5 \mathrm{M}-\mathrm{HCl}$ and made up to an appropriate volume with $\mathrm{LaCl}_{2}$ solution $(1 \mathrm{~g} / \mathrm{l}) . \mathrm{Mg}$ and $\mathrm{Ca}$ were measured by atomic absorption spectrophotometry (Perkin-Elmer 420, Norwalk, CT) in an acetylene air flame at a wavelength of 285 and $422 \mathrm{~nm}$ respectively. $P_{i}$ was measured by a colorimetric method at $690 \mathrm{~nm}$ using a commercial kit (Biotrol, Paris, France). The previously described methods were checked against reference material from National Institute of Standards and Technology (Standard Reference Material 1548); the coefficient of variation was estimated for $\mathrm{Ca}, \mathrm{Mg}$ and $\mathrm{P}_{\mathrm{i}}$ respectively at $1.8,1.6$ and $2.0 \%$ for a diet matrix and at $2 \cdot 2,1.9$ and $2.5 \%$ for a faeces matrix.

\section{Calculations and statistical analyses}

The entire caecal contents were determined as caecal concentration $(\mu \mathrm{mol} / \mathrm{ml}) \times$ caecal water $(\mathrm{ml})$, and the rate of caecal absorption (at the time of the measurement) as caecal vein - artery difference $(\mu \mathrm{mol} / \mathrm{ml} \mathrm{plasma}) \times$ caecal plasma flow $(\mathrm{ml} / \mathrm{min})$. For the determination of digestive balance, food and faecal samples from each rat, collected over $4 \mathrm{~d}$, were homogenized before mineral analysis. Intake of $\mathrm{Ca}$ via the drinking water was considered to be negligible $(<0.5 \mathrm{mg} / 1)$ compared with that from the diet and was not considered.

Values are given as means with their standard errors and, where appropriate, significance 
of differences between mean values was determined by two-way ANOVA. Statistical analyses of the data were carried out according to the methods described by Snedecor $\&$ Cochran (1989). When data for the treatment groups did not meet the assumption of equal variance, observations were transformed logarithmically and these transformed values were used for the subsequent statistical examinations. Values of $P<0.05$ were considered significant.

\section{RESULTS}

Changes in food intake, body weight and caecal digestion

Diets containing RS were well tolerated by the rats, provided that the level of $350 \mathrm{~g} \mathrm{raw}$ potato starch $/ \mathrm{kg}$ in the food was progressively reached, within 3-4 d, at the beginning of the $15 \mathrm{~d}$ adaptation period. As shown in Table 2, the daily food intake was not significantly affected by the diet, but the weight gain was slightly lower in rats adapted to the RS diets than in those fed on the DS diets. In contrast, dietary $\mathrm{Ca}$ intake had practically no effect on food intake or the growth of the rats.

The presence of $350 \mathrm{~g}$ raw potato starch $/ \mathrm{kg}$ in the diet resulted in an enlargement of the caecum, corresponding to a 3-4-fold increase in the caecal contents together with hypertrophy of the caecal wall (Table 2). In rats fed on the RS diets the caecum was slightly heavier in animals fed at the low-Ca intake, compared with those fed at the high-Ca intake. Caecal blood flow was markedly higher in rats fed on RS diets (in the range of 3.2-3.5 $\mathrm{ml} / \mathrm{min} v$. about $0.9 \mathrm{ml} / \mathrm{min}$ with the DS diets); the dietary Ca level had no noticeable effect on caecal blood flow. The dry matter level in the caecal contents was significantly higher in rats fed on the RS diets. Caecal pH was close to neutrality in rats fed on the DS diets, and it was not influenced by the dietary $\mathrm{Ca}$ level. In contrast, dietary $\mathrm{Ca}$ intake influenced the acidification of caecal contents in rats fed on RS diets: the $\mathrm{pH}$ fell to 5 in rats adapted to $2.5 \mathrm{~g} \mathrm{Ca} / \mathrm{kg}$ diet compared with 5.7 with the high dietary $\mathrm{Ca}$ intake.

Table 3 shows that some SCFA were produced from endogenous substrates in rats fed on DS diets, at a pH close to neutrality. In the case of acidic fermentation (rats fed on RS diets) the dietary $\mathrm{Ca}$ intake markedly influenced the quantities of organic acids present in the caecum. In rats adapted to the $7.5 \mathrm{~g} \mathrm{Ca} / \mathrm{kg}$ diet there was a high concentration of SCFA in the caecum (approximately $160 \mathrm{mmol} / \mathrm{l}$ ) together with lactic acid (approximately 80 $\mathrm{mmol} / \mathrm{l}$ ). With the low-Ca diet the very acidic fermentation was characterized by a lower concentration of SCFA (approximately $100 \mathrm{mmol} / \mathrm{l}$ ) but lactic acid concentration was still in the range of $80 \mathrm{mmol} / 1$. Due to the differences in caecal weight between the two dietary $\mathrm{Ca}$ levels, the entire caecal content of SCFA was higher with the $7.5 \mathrm{~g} \mathrm{Ca} / \mathrm{kg}$ diet and that of lactic acid was higher with the $2.5 \mathrm{~g} \mathrm{Ca} / \mathrm{kg}$ diet. Nevertheless, the caecal content of monocarboxylic acids (SCFA+lactic acid) was not markedly different (in the range $1300-1400 \mu \mathrm{mol})$ between the two dietary Ca levels.

In rats fed on the DS diets the molar ratio of caecal SCFA (acetate:propionate: butyrate) was about $62: 25: 13$, without any effect of dietary Ca. In rats fed on the RS diet with $2.5 \mathrm{~g}$ $\mathrm{Ca} / \mathrm{kg}$, fermentation was characterized by a high proportion of acetic acid and low proportion of propionic acid. In rats fed on the RS diet with $7 \cdot 5 \mathrm{~g} \mathrm{Ca} / \mathrm{kg}$, along with a high SCFA concentration there was a different SCFA molar ratio $(50: 27: 23)$, corresponding to higher concentrations of propionic and butyric acid (about $40 \mathrm{mmol} / \mathrm{l}$ ). The high concentrations of lactic acid present in rats fed on RS diets were essentially in the form of L-lactic (L:D approximately 3 ) and this was not influenced by the dietary $\mathrm{Ca}$ intake.

\section{Changes in caecal availability of calcium and inorganic phosphate}

Dietary $\mathrm{Ca}$ influenced greatly the accumulation of $\mathrm{Ca}$ in the large intestine since this mineral, when present in excess, is essentially eliminated in the faeces. Rats fed on the DS diets had the same concentration of soluble $\mathrm{Ca}$ in caecal contents (about $12 \mathrm{mmol} / \mathrm{l}$ ) 


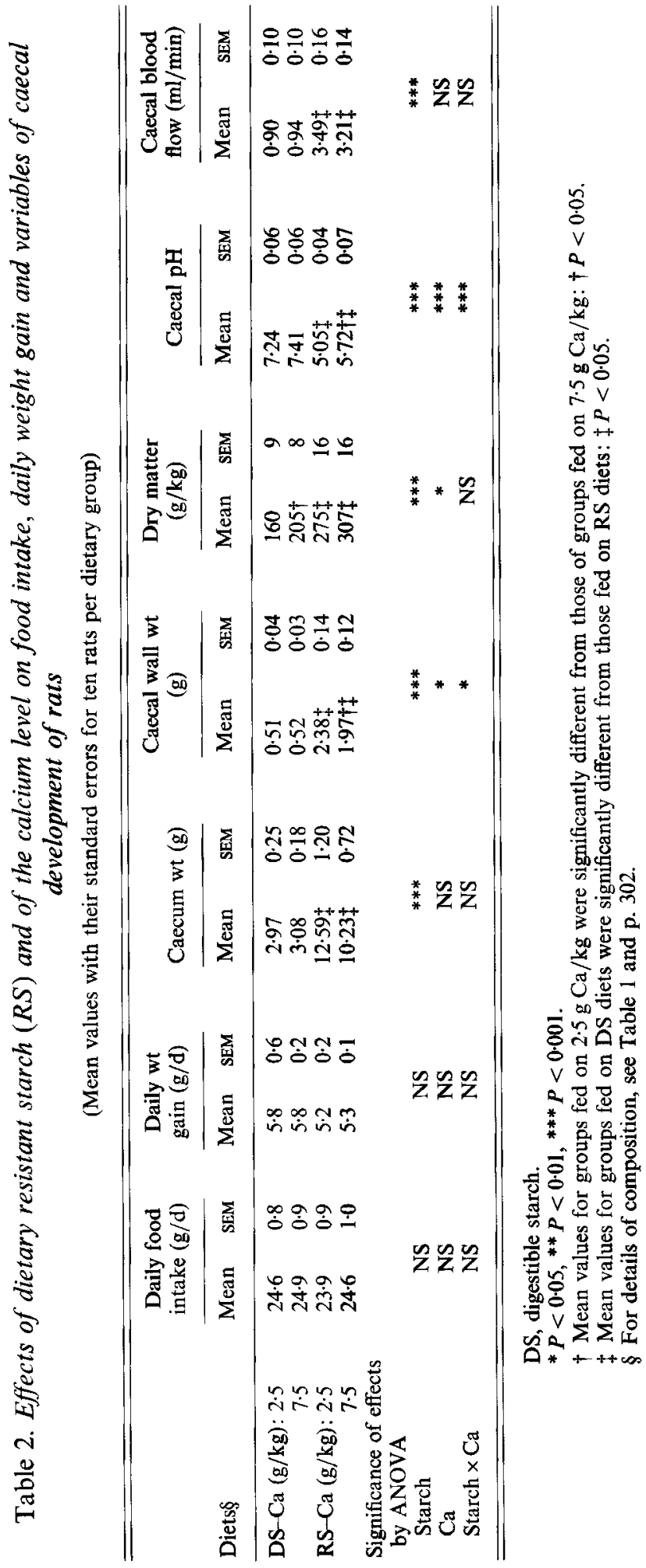


H. YOUNES AND OTHERS

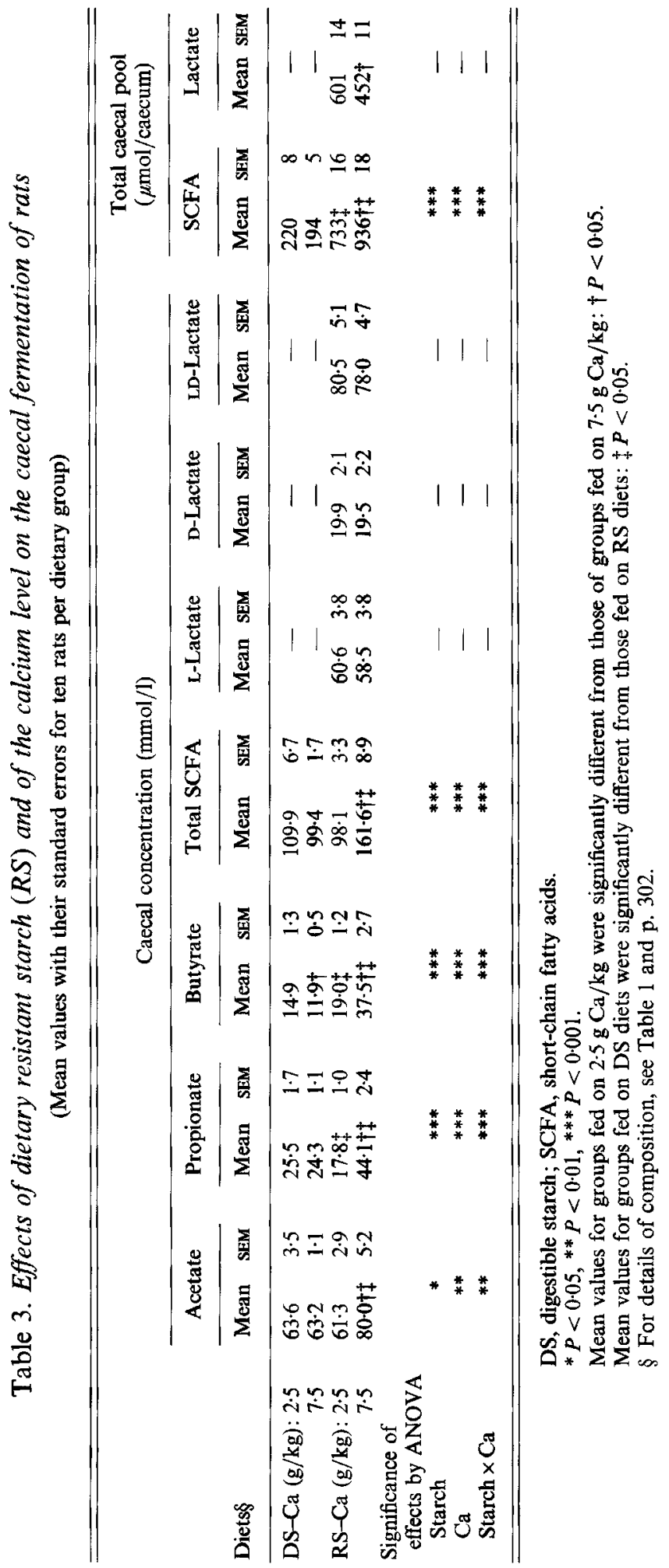




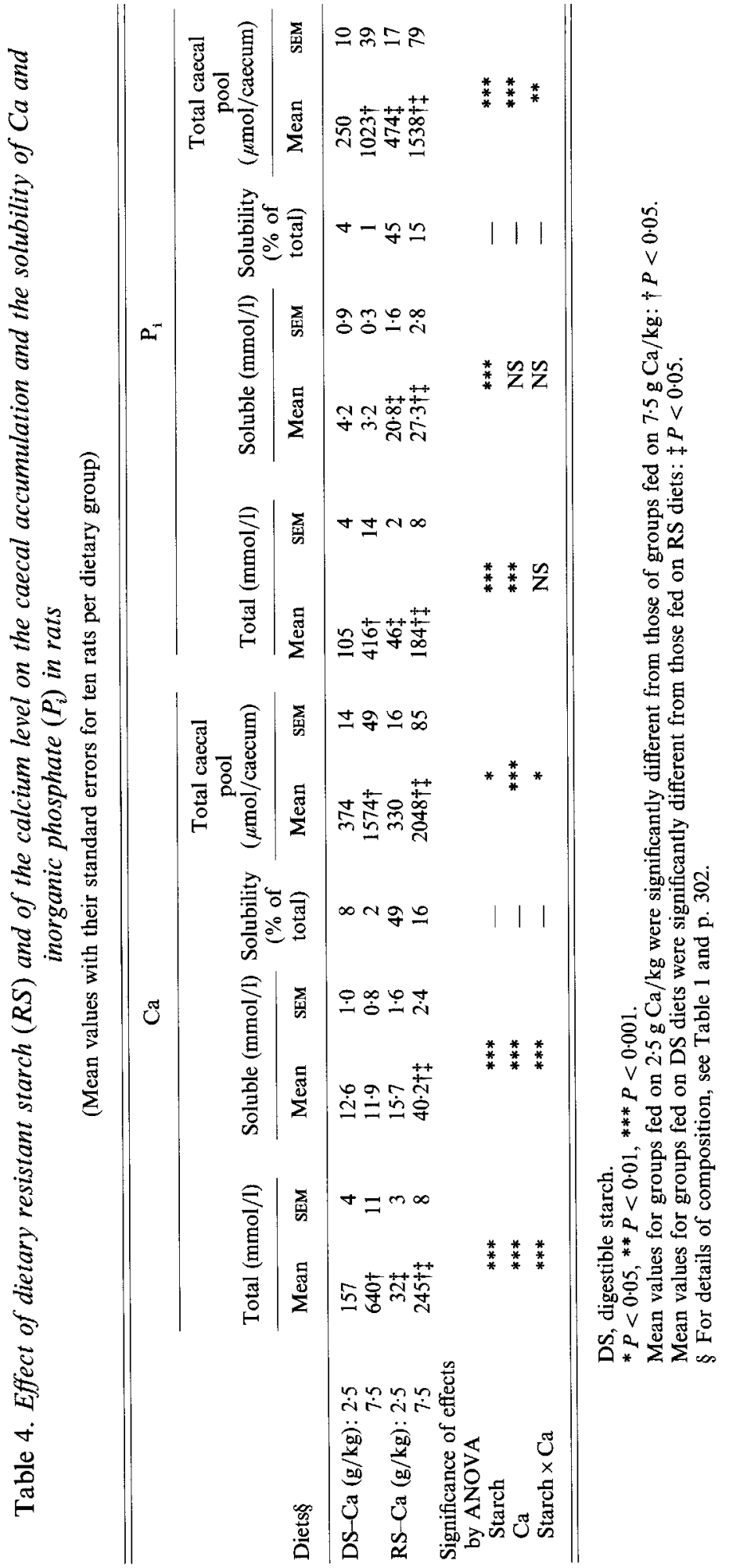



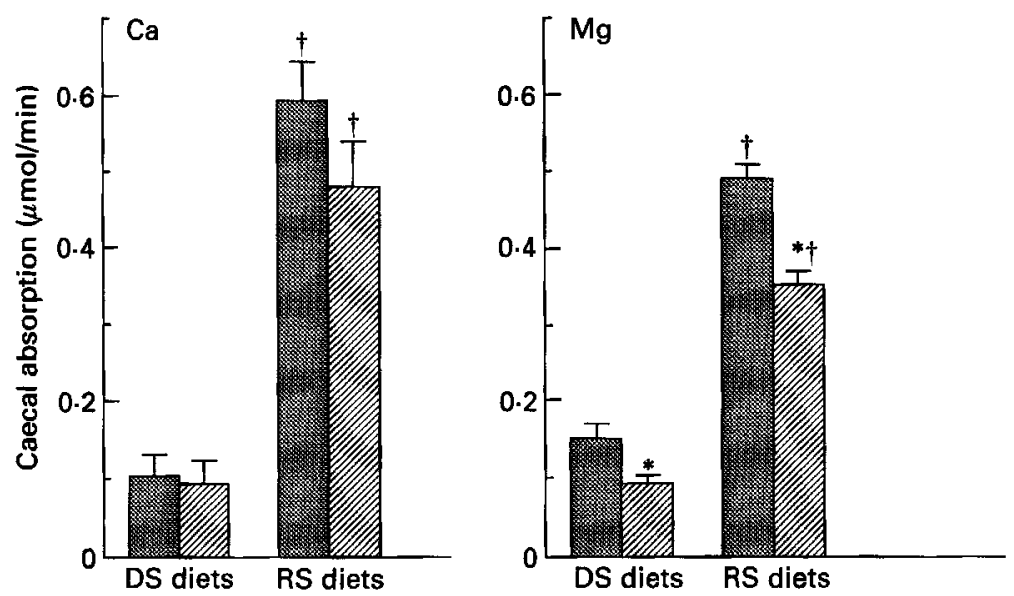

Fig. 1. Changes in calcium or magnesium absorption from the caecum of rats adapted to digestible-starch (DS) or resistant-starch (RS) diets, and to a 2.5 (圆) or a $7.5(\mathrm{Q}) \mathrm{g} \mathrm{Ca} / \mathrm{kg}$ level. For details of diets and procedures, see pp. 302-303 and Table 1. Values are means with their standard errors, represented by vertical bars, for ten rats per group. Mean values for groups of rats fed on $7.5 \mathrm{~g} \mathrm{Ca} / \mathrm{kg}$ were significantly different from those for groups of rats fed on $2.5 \mathrm{~g} \mathrm{Ca} / \mathrm{kg}$ : ${ }^{*} P<0.05$. Mean values for groups of rats fed on the RS diet were significantly different from those for groups of rats fed on the DS diet: $+P<0.05$.

whatever the dietary $\mathrm{Ca}$ level (Table 4). At neutral $\mathrm{pH}, \mathrm{Ca}$ was mainly insoluble (in the form of $\mathrm{Ca}-\mathrm{P}_{\mathbf{i}}$ complex) and the $\mathrm{P}_{\mathbf{i}}$ concentration (and solubility) varied in parallel to that of $\mathrm{Ca}$, with a relatively constant $\mathrm{Ca}: \mathrm{P}_{i}$ value of about 1.5 . The caecal accumulation of $\mathrm{Ca}-\mathrm{P}_{i}$ was considerable in rats fed on the DS-high-Ca diet (1574 and $1023 \mu \mathrm{mol}$ for $\mathrm{Ca}$ and $\mathrm{P}_{\mathrm{i}}$ respectively). In rats fed on the $\mathrm{RS}$ diets the total $\mathrm{Ca}$ was diluted in a large volume; at $2.5 \mathrm{~g} \mathrm{Ca} / \mathrm{kg}$ a particularly low $\mathrm{Ca}$ concentration was found in the caecum $(32 \mathrm{mmol} / \mathrm{l})$. In rats fed on the low $\mathrm{Ca}$ level the caecal concentration of soluble $\mathrm{Ca}(16 \mathrm{mmol} / \mathrm{l})$ was not noticeably affected by feeding RS. However, the percentage of soluble Ca was dramatically increased (from 8 in rats fed on DS diets to 49 in rats fed on RS diets). The entire caecal content of $\mathrm{Ca}$ was significantly increased by $\mathrm{RS}$ only in rats adapted to the $7.5 \mathrm{~g} \mathrm{Ca} / \mathrm{kg}$ level. Ca solubility was also enhanced in rats fed on the RS-high-Ca diet; the soluble Ca reached $40 \mathrm{mmol} / \mathrm{l}$ compared with $12 \mathrm{mmol} / 1$ in rats fed on DS diets. Dietary RS also affected the quantities and the solubility of $\mathrm{P}_{1}$ in caecal contents. As for $\mathrm{Ca}$, a decrease in $P_{i}$ concentration was observed in rats fed on $R S$ diets, in parallel with a 3-4-fold enlargement of the caecum; the accumulation of $\mathrm{P}_{1}$ was markedly higher with the high $\mathrm{Ca}$ level. Changes in soluble $P_{1}$ concentrations were relatively parallel with those of $\mathrm{Ca}$, the percentage of soluble $P_{1}$ being higher in rats fed on the RS diets than in control (DS-fed) rats. The elevation of the $P_{i}$ solubility by the RS diet was particularly significant with the low $\mathrm{Ca}$ level (from 4 to $45 \%$ ).

\section{Digestive absorption of calcium and inorganic phosphate}

In the rat there is an efficient absorption of $\mathrm{Ca}$ by the caecum, which can be quantified by measurement of arterio-venous differences (Fig. 1); in contrast, $\mathrm{P}_{\mathrm{i}}$ was not absorbed in significant amounts. In rats fed on DS diets $\mathrm{Ca}$ absorption by the caecum was low and was not responsive to changes in the level of dietary Ca. Rats fed on RS diets had a 5-6-fold higher caecal $\mathrm{Ca}$ absorption than rats fed on DS diets; however, there was no significant difference between the two $\mathrm{Ca}$ levels, despite a marked difference in soluble $\mathrm{Ca}$ in the caeca of rats adapted to RS. It must be noted that this rise in the caecal absorption of Ca was a reflection of both accelerated blood flow $(+250-300 \%)$ and greater arterio-venous differences $(+30-50 \%)$. Table 5 shows that, in control rats, the difference (Ca intake $-\mathrm{Ca}$ 


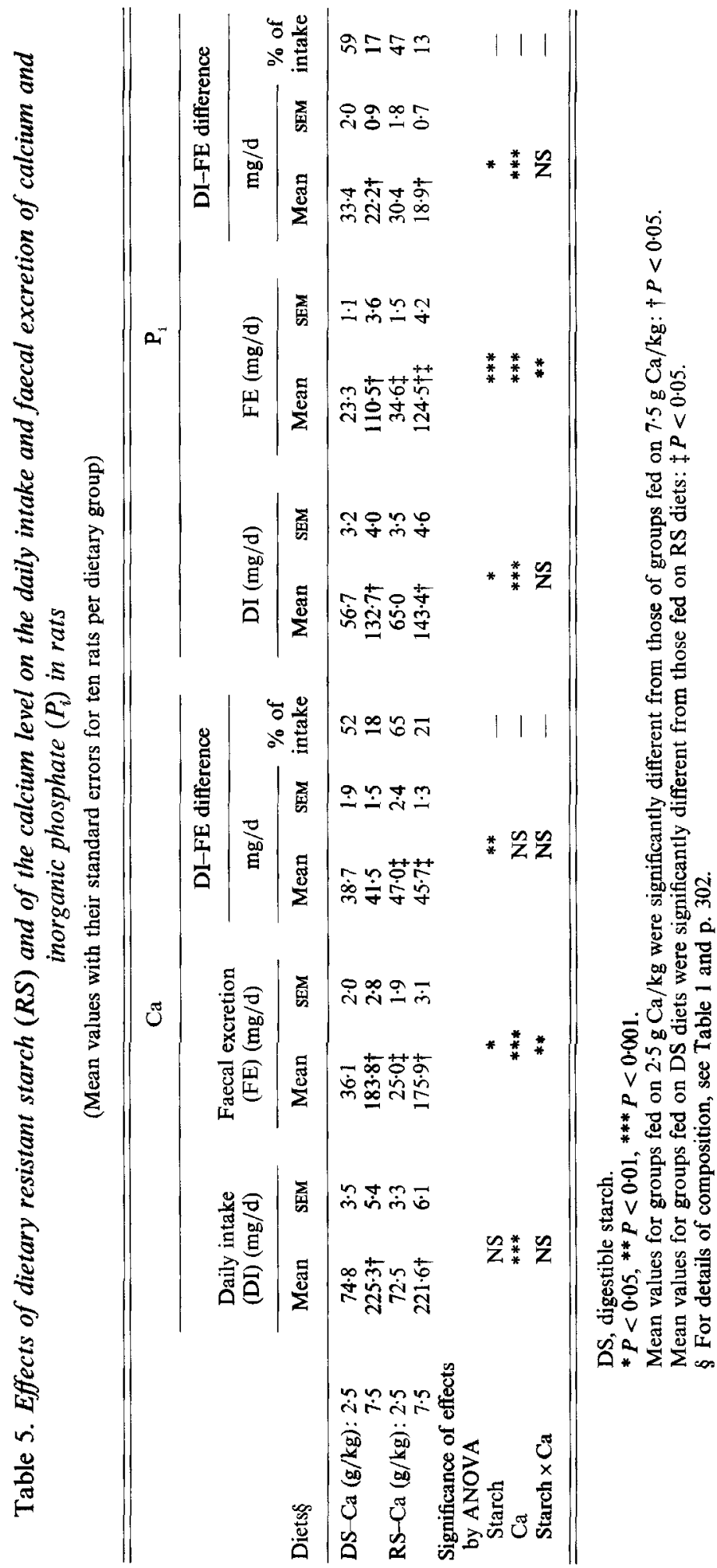


Table 6. Effects of dietary resistant starch $(R S)$ and of the calcium level on magnesium digestive balance in rats

(Mean values with their standard errors for ten rats per dietary group)

\begin{tabular}{|c|c|c|c|c|c|c|c|c|c|}
\hline \multirow[b]{3}{*}{ Diets§ } & \multirow{2}{*}{\multicolumn{2}{|c|}{$\begin{array}{l}\text { Daily intake } \\
\text { (DI) }(\mathrm{mg} / \mathrm{d})\end{array}$}} & \multirow{2}{*}{\multicolumn{2}{|c|}{$\begin{array}{c}\text { Faecal } \\
\text { excretion (FE) } \\
(\mathrm{mg} / \mathrm{d})\end{array}$}} & \multicolumn{3}{|c|}{ DI-FE difference } & \multirow{2}{*}{\multicolumn{2}{|c|}{$\begin{array}{c}\text { Plasma } \\
\text { concentration } \\
(\mathrm{mmol} / \mathrm{l})\end{array}$}} \\
\hline & & & & & \multicolumn{2}{|c|}{$\mathrm{mg} / \mathrm{d}$} & \multirow{2}{*}{$\begin{array}{l}\% \text { of } \\
\text { intake }\end{array}$} & & \\
\hline & Mean & SEM & Mean & SEM & Mean & SEM & & Mean & SEM \\
\hline DS Ca $(\mathrm{g} / \mathrm{kg}): 2.5$ & $20 \cdot 1$ & 0.9 & $12 \cdot 0$ & 0.7 & $8 \cdot 1$ & 0.4 & 40 & 0.95 & 0.04 \\
\hline 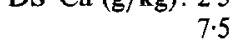 & $21 \cdot 1$ & $1 \cdot 1$ & $17.0 \dagger$ & 0.8 & $4 \cdot 1 \dagger$ & 0.3 & 19 & $0.81 \dagger$ & 0.03 \\
\hline $\mathrm{RS}-\mathrm{Ca}(\mathrm{g} / \mathrm{kg}): 2.5$ & $20 \cdot 2$ & 1.0 & $8 \cdot 1 \ddagger$ & 0.6 & $12 \cdot 1 \div$ & 0.9 & 60 & 0.92 & 0.03 \\
\hline 7.5 & $21 \cdot 3$ & 1.3 & $14 \cdot 1+\ddagger$ & 1.0 & $7 \cdot 2+7$ & 0.7 & 34 & 0.86 & 0.04 \\
\hline \multirow{2}{*}{\multicolumn{10}{|c|}{$\begin{array}{l}\text { Significance of effects } \\
\text { by ANOVA }\end{array}$}} \\
\hline & NS & & $* * *$ & & *** & & & & \\
\hline $\mathrm{Ca}$ & \multicolumn{2}{|c|}{ NS } & \multicolumn{2}{|c|}{$* * *$} & \multicolumn{2}{|c|}{$* * *$} & - & \multicolumn{2}{|c|}{$* *$} \\
\hline Starch $\times \mathrm{Ca}$ & \multicolumn{2}{|c|}{ NS } & \multicolumn{2}{|c|}{ NS } & \multicolumn{2}{|c|}{ NS } & - & \multicolumn{2}{|c|}{ NS } \\
\hline
\end{tabular}

DS, digestible starch.

** $P<0.01, * * * P<0.001$.

Mean values for groups fed on $2.5 \mathrm{~g} \mathrm{Ca} / \mathrm{kg}$ were significantly different from those of groups fed on $7 \cdot 5 \mathrm{~g} \mathrm{Ca} / \mathrm{kg}$ : $\dagger P<0.05$.

Mean values for groups fed on DS diets were significantly different from those fed on RS diets: $\ddagger P<0 \cdot 05$.

$\S$ For details of composition, see Table 1 and p. 302 .

faecal excretion) was not affected by increasing the dietary $\mathrm{Ca}$ intake. Furthermore, in rats fed on the high-Ca diets the presence of RS in the diet failed to alter this difference. However, rats fed on a RS diet with a low $\mathrm{Ca}$ level showed a higher (Ca intake- $\mathrm{Ca}$ fecal excretion) difference, compared with rats fed on the low-Ca-DS diet. Despite changes in the availability of dietary $\mathrm{Ca}$ or of complex carbohydrate, plasma $\mathrm{Ca}$ concentration was unchanged in the experimental groups (values not presented). A high dietary intake of $\mathrm{Ca}$ depressed significantly the $\mathrm{P}_{\mathrm{i}}$ difference (intake-faecal excretion) difference, probably because $\mathrm{Ca}$ tends to attract $\mathbf{P}_{\mathrm{i}}$ into the large intestine. RS failed to counteract significantly the negative effect of $\mathrm{Ca}$ on $\mathrm{P}_{\mathrm{i}}$.

\section{Change in caecal magnesium availability and in magnesium absorption}

In rats adapted to DS diets, the dietary Ca level had no effect on the amount of $\mathrm{Mg}$ present in caecal contents (range 230-255 $\mu \mathrm{mol}$ ); nevertheless, $\mathrm{Mg}$ solubility was lower in rats fed on diets containing a high $\mathrm{Ca}$ level, in parallel with $\mathrm{Ca}-\mathrm{P}_{\mathrm{i}}$ accumulation. In rats fed on RS diets a higher volume of caecal contents reduced $\mathrm{Mg}$ concentration, from about 100 $\mathrm{mmol} / \mathrm{l}$ in rats fed on the DS diets to about $25 \mathrm{mmol} / \mathrm{l}$ in those fed on the RS diets (values not presented). The caecum appeared to be a site of $\mathrm{Mg}$ absorption, even in rats fed on the DS diets (Fig. 1). The enlargement of the caecum in rats fed on RS diets corresponded to a 3-4-fold higher caecal $\mathrm{Mg}$ absorption compared with control (DS) rats. A high Ca intake resulted in a lower $\mathrm{Mg}$ absorption by the caecum, consistent with the fall in soluble $\mathrm{Mg}$ described previously.

As with caecal absorption, dietary $\mathrm{Ca}$ exerted a negative effect on $\mathrm{Mg}$ digestibility, which was 40 or $19 \%$ respectively in rats adapted to DS diets containing 2.5 or $7.5 \mathrm{~g} \mathrm{Ca} / \mathrm{kg}$, (Table 6). Compared with the DS diet the RS diet markedly improved $\mathrm{Mg}$ digestive balance; $\mathrm{Mg}$ digestibility was higher with the low dietary $\mathrm{Ca}$ level. In rats fed on RS diets 
the dietary $\mathrm{Ca}$ level had no noticeable effect on plasma $\mathrm{Mg}$; however, magnesaemia was significantly depressed by the high $\mathrm{Ca}$ level when rats were adapted to DS.

\section{DISCUSSION}

Compared with some soluble fibres $\mathrm{RS}$ is devoid of uronic acids which can chelate divalent cations. Thus, the effects of RS on mineral digestibility seems essentially a consequence of colonic fermentation. The present work also indicates that the bioavailability of major minerals, especially $\mathrm{Ca}$ and $\mathbf{P}_{\mathrm{i}}$, plays an important role in the stability of symbiotic fermentation (SCFA-rich type) and the control of lumen $\mathrm{pH}$ in the large intestine. In contrast, fermentation may result in a higher absorption of divalent cations.

Enlargement of the caecum in rats consuming unavailable carbohydrates (fermentable fibres or RS) has been reported consistently (Würsch, 1989; Goodlad \& Mathers, 1990; Levrat et al. 1991 b). The effect of complex carbohydrates on caecal hypertrophy tends to be proportional to their fermentability rather than merely to their accumulation in the caecum; accordingly, poorly-fermentable fibres (e.g. oat hull fibre) have little influence on the caecum size (Rémésy et al. 1992). In the present study the caecum of rats fed on RS diets (digesta contents + caecal wall) was markedly enlarged (3-4-fold), which results in a dilution of minerals coming from the small intestine and in a greater surface area for absorption. Under such conditions it has been reported that the height of crypt columns and the number of cells per crypt is markedly enhanced (Rémésy et al. 1993). SCFA probably represent important stimuli for the colonic cell proliferation frequently observed after feeding fibre (Lupton \& Kurtz, 1993); it is conceivable that this trophic effect might result in a more effective absorption of $\mathrm{Ca}$.

There is a permanent influx of minerals into the large intestine from the ileum, and the dietary level of the minerals certainly influences their bioavailability in the caecum. This appears particularly relevant for $\mathrm{Ca}$; with a high dietary level of $\mathrm{Ca}$ large amounts of this cation tend to accumulate in the large intestine, and the major part of $\mathrm{Ca}$ is probably present as an insoluble $\mathrm{Ca}-\mathrm{P}_{\mathrm{i}}$ complex at physiological $\mathrm{pH}$. The $\mathrm{P}_{1}$ concentration appears essentially governed by that of $\mathrm{Ca}$; the $\mathrm{Ca}: \mathrm{P}_{i}$ ratio was generally $>1$, especially in rats fed on the high-Ca-fibre-free (DS) diet $\left(\mathrm{Ca}: \mathrm{P}_{\mathrm{i}}\right.$ ratio: 1 -54). The presence in the caecum of a $\mathrm{pH}-$ buffering system involving the $\mathrm{Ca}-\mathrm{P}_{i}$ pool has been described in rats fed on inulin (Rémésy et al. 1993). Such a pool of insoluble Ca (devoid of osmotic effect) may be effective in counteracting caecal acidification when there is very active fermentation. Schulz et al. (1993) have reported also that $\mathrm{RS}$ lowers the $\mathrm{pH}$ and raises the Ca concentration in caecal water. In rats fed on DS diet the buffering capacity of caecal contents was very high, even with the low-Ca diet (total Ca $157 \mathrm{mmol} / \mathrm{l}$ ), because electrolytes from the ileal effluent were concentrated in a small volume. In contrast, in rats adapted to the low-Ca-RS diet, effective absorption of $\mathrm{Ca}$ in the upper digestive tract, together with a dilution of unabsorbed $\mathrm{Ca}$ in a large caecal volume, led to lower caecal $C a$ and $P_{i}$ concentrations $(30-40 \mathrm{mmol} / 1)$. Generally, when a variety of dietary fibre is fermented in the caecum the main endproducts of bacterial fermentations are SCFA, with a marginal production of lactic acid (Rémésy et al. 1992, 1993). The presence of large quantities of fermentable substrates in the caecum of rats fed on raw potato starch offered conditions favourable to the production of both SCFA and lactic acid isomers. It is generally accepted that a very acidic $\mathrm{pH}$ (about 5) inhibits micro-organisms which metabolize lactic acid (Cummings, 1981); yet, a noticeable production of lactic acid was also observed at $\mathrm{pH} 5 \cdot 7(7 \cdot 5 \mathrm{~g} \mathrm{Ca} / \mathrm{kg}$ level). A direct influence of minerals on caecal fermentation is still uncertain; it is noteworthy that propionic and butyric acid concentrations were significantly depressed in the caecum of rats fed on the low-Ca diet, but this could result from excessive acidification.

Ca absorption in the small intestine is strictly regulated (Bronner et al. 1986); thus, the 
quantities of $\mathrm{Ca}$ reaching the large intestine are not directly proportional to the dietary $\mathrm{Ca}$ intake. With the $2.5 \mathrm{~g} \mathrm{Ca} / \mathrm{kg}$ level, the disappearance of $\mathrm{Ca}$ in the small intestine was high and RS seems to have little effect on this process. In contrast, there was a net increase in Ca present in the caecum of rats fed on the RS diet containing $7.5 \mathrm{~g} \mathrm{Ca} / \mathrm{kg}$. Hypertrophy of the caecum at acidic $\mathrm{pH}$ with $\mathrm{RS}$ diets strongly stimulates $\mathrm{Ca}$ absorption in distal absorptive sites. A high rate of $\mathrm{Ca}$ absorption in the large intestine could trigger a feedback mechanism involving an inhibition of duodenal absorption, since there is a control of the digestive balance of $\mathrm{Ca}$ by endocrine factors (Nellans \& Goldsmith, 1981; Bronner et al. 1986). The rat caecum presents the highest density of $\mathrm{Ca}$ transport sites (responsive to vitamin $\mathrm{D}$ metabolites); however, $\mathrm{Ca}$ absorption is restricted when $\mathrm{Ca}$ is in an unabsorbable form (Nellans \& Goldsmith, 1981; Amman et al. 1986). Thus, fermentable carbohydrates could favour $\mathrm{Ca}$ absorption in the distal part of the digestive tract in several ways: hypertrophy of the caecal wall and greater surface area, increase in soluble $\mathrm{Ca}$, and accelerated blood flow.

Although the affinity of the Ca transport system seems high $\left(\mathrm{K}_{\mathrm{t}}\right.$ value at ${ }^{\frac{1}{2}} V_{\max }$ being approximately $1 \mathrm{mM}$; Favus, 1985), the solubilization of $\mathrm{Ca}$ by organic acids probably plays an essential role in the enhanced contribution of the caecum to overall digestive absorption (caecal soluble Ca $24 \mu \mathrm{mol}$ in both DS-diet groups, compared with 120 and $230 \mu \mathrm{mol}$ in rats fed on RS diets containing 2.5 or $7.5 \mathrm{~g} \mathrm{Ca} / \mathrm{kg}$ diets respectively). Moreover, an increase in total transport sites due to caecal hypertrophy could elevate the rate of absorption of solubilized $\mathrm{Ca}$. It is possible also that SCFA directly influence $\mathrm{Ca}$ absorption by modifying various electrolyte exchanges $(\mathrm{Ca}-\mathrm{H})$ and Trinidad et al. (1993) have proposed that $\mathrm{Ca}$ could pass through the cell membrane more readily in the form of a less-charged complex $(\mathrm{CaAc})^{+}$. Lutz \& Scharrer (1991) have also reported a stimulatory effect of SCFA on $\mathrm{Ca}$ absorption in the rat large intestine. In fact, there are probably several factors which affect $\mathrm{Ca}$ absorption (caecal $\mathrm{pH}, \mathrm{SCFA}$ concentration, $\mathrm{Ca}$ itself) and the question arises whether SCFA have a direct effect on the lumen or affect passive $\mathrm{Ca}$ absorption due to the hypertrophy of the caecum.

$\mathrm{Ca}$ availability in the large intestine has been the subject of various investigations since it may exert a protective effect on the colon epithelium (Wargovich et al. 1983) and inhibit the cytotoxicity of potential carcinogens, such as bile acids or fatty acids (Lapre et al. 1991; Gorvers \& Van der Meer, 1992). It must be noted that in rats adapted to the low-Ca-RS diet butyric acid and propionic acid concentrations were depressed, which may be physiologically relevant since these acids (especially butyric acid) are considered as inhibitors of cell proliferation as well as differentiation inducers in several types of cancer cells (Kruh, 1982; Gamet et al. 1992).

Compared with $\mathrm{Ca}$, the importance of the distal part of the digestive tract for $\mathrm{Mg}$ absorption is well documented (Hardwick et al. 1990; Karbach \& Rummel, 1990) and it has been shown previously that various types of RS stimulate $\mathrm{Mg}$ absorption (Rayssiguier \& Rémésy, 1977; Schulz et al. 1993). As with Ca, fermentable carbohydrates may raise the pool of soluble $\mathrm{Mg}$ in the large intestine by acidifying digesta contents ( $\mathrm{Mg}$ solubility being generally higher than that of $\mathrm{Ca}$ ). It is noteworthy that $\mathrm{Mg}$ solubility tends to fall when large amounts of insoluble $\mathrm{Ca}-\mathrm{P}_{\mathrm{i}}$ complex are present in the caecum. The striking effect of RS diets on caecal absorption of $\mathrm{Mg}$ (4-fold increase) probably resulted from (1) caecal hypertrophy, (2) Mg solubilization and (3) possibly, a specific effect of SCFA (Scharrer \& Lutz, 1992). Indeed, SCFA are predominantly absorbed in an undissociated form in the large intestine, although they mainly occur as anions in the lumen (Rechkemmer et al. 1988). Protons needed for SCFA absorption may be delivered by various ion exchangers (including $\mathrm{Mg}-\mathrm{H}$ ); in return SCFA absorption at acidic $\mathrm{pH}$ would supply more protons to the exchangers, resulting in a higher transport rate (Lutz et al. 1991). Feeding RS had a 
greater effect on the apparent digestive balance of $\mathrm{Mg}$ than on that of $\mathrm{Ca}$. The possibility of a negative feedback in response to a highly effective absorption in the large intestine seems less likely for $\mathrm{Mg}$ than for $\mathrm{Ca}$. This is in accordance with the fact that $\mathbf{M g}$ absorption is more efficient in the ileum and the large intestine (Hardwick et al. 1990). A high dietary Ca supply consistently led to an inhibition of $\mathrm{Mg}$ absorption in the caecum and a reduction in $\mathrm{Mg}$ digestibility. In contrast to the divalent cations, it was not possible to detect any significant absorption of $P_{1}$ in the large intestine (by arterio-venous difference). Since high Ca concentrations promote precipitation of $P_{1}$ and inhibit its intestinal absorption, this $P_{1}$ transfer into the large intestine depressed the digestive balance of $P_{i}$. This balance was not affected by $\mathbf{R S}$ feeding despite increased caecal content of $\mathbf{P}_{\mathbf{i}}$.

In conclusion, the enhancement of $\mathrm{Ca}$ absorption in the large intestine by increasing colonic fermentation may be of particular interest when the overall process of digestive absorption is inefficient, such as in elderly subjects (Andon et al. 1993). In humans, a role for the colon is supported by the observation that the large intestine is able to maintain a near-normal rate of $\mathrm{Ca}$ absorption in cases of small intestinal resection (Hylander et al. 1980). In humans, RS may also lower the colon lumen $\mathrm{pH}$, even if the daily intake is much lower than that in the present work (Englyst et al. 1992) and the fermentation rate of raw potato starch is low (Olesen et al. 1994). The Ca content of the human diet is usually about $1 \mathrm{~g} / \mathrm{kg}$, i.e. much less than that in the present study; nevertheless, such a dietary supply leads to the accumulation of high $\mathrm{Ca}-\mathbf{P}_{\mathrm{i}}$ concentrations in human faeces (Lapré et al. 1991 ) and it seems likely that $\mathrm{Ca}$ solubility in the large intestine is also influenced by polysaccharide fermentation. Simultaneous supplementation of the diet with $\mathrm{Ca}$ and fermentable carbohydrate (RS and/or plant foods rich in soluble fibre) seems advantageous to promote fermentation, to counteract the negative effect of dietary $\mathrm{Ca}$ on $\mathrm{Mg}$ digestibility and to stimulate $\mathrm{Ca}$ absorption in the large intestine. Finally, microbial fermentation appears to have a major influence on the efficiency of $\mathrm{Ca}$ absorption in the large intestine.

\section{REFERENCES}

Amman, P., Rizzoli, R. \& Fleisch, H. (1986). Calcium absorption in rat large intestine in vivo: availability of dietary calcium. American Journal of Physiology 251, G14-G18.

Andon, M. B., Kanerva, R. L., Schulte, M. C. \& Smith, K. T. (1993). Effect of age, calcium source, and radiolabeling method on whole body ${ }^{47} \mathrm{Ca}$ retention in the rat. American Journal of Physiology 265, E554-E558.

Andrieux, C., Gadelle, D., Leprince, C. \& Sacquet, E. (1989). Effects of some poorly digestible carbohydrates on bile acid bacterial transformations in the rat. British Journal of Nutrition 62, 103-119.

Bronner, F., Pansu, D. \& Stein, W. D. (1986). An analysis of intestinal calcium transport across the rat intestine. American Journal of Physiology 250, G561-G569.

Cummings, J. H. (1981). Short-chain fatty acids in the human colon. Gut 16, 323-329.

Cummings, J. H., Southgate, D. A. T., Branche, W. J., Wiggins, H. S., Houston, H., Jenkins, D. J. A., Jivraj, T. \& Hill, M. (1979). The digestion of pectin in the human gut and its effects on calcium absorption and large bowel functions. British Journal of Nutrition 41, 477-485.

Demigné, C. \& Rémésy, C. (1985). Stimulation of absorption of volatile fatty acids and minerals in the caecum of rats adapted to very high fiber diet. Journal of Nutrition 115, 53-60.

Demigné, C., Levrat, M.-A. \& Rémésy, C. (1989). Effects of feeding fermentable carbohydrates on the caecal concentrations of minerals and their fluxes between caecum and blood plasma in the rat. Journal of Nutrition 119, 1625-1630.

Demigné, C., Rémésy, C. \& Rayssiguier, Y. (1980). Effects of fermentable carbohydrates on volatile fatty acids, ammonia and mineral absorption in the rat caecum. Reproduction, Nutrition, Développement 20, 1351-1359.

Donagelo, C. M. \& Eggum, B. O. (1986). Comparative effects of wheat bran and barley husk on nutrient utilization in rats. 2. Zinc, calcium and phosphorus. British Journal of Nutrition 56, 269-280.

Englyst, H. N., Kingman, S. M. \& Cummings, J. H. (1992). Classification and measurement of nutritionally important starch fractions. European Journal of Clinical Nutrition 46, Suppl. 2, S33-S50.

Favus, M. J. (1985). Factors that influence absorption and secretion of calcium in the small intestine and colon. American Journal of Physiology 248, G147-G157.

Gamet, L., Daviaud, D., Denis-Pouxviel, C., Rémésy, C. \& Murat, J.-C. (1992). Effects of short-chain fatty acids on growth and differentiation of human colon-cancer cell line HT29. International Journal of Cancer $\mathbf{5 2}$, $286-289$. 
Goodlad, J. S. \& Mathers, J. C. (1990). Large bowel fermentation in rats given diets containing raw peas (Pisum sativum). British Journal of Nutrition 64, 569-587.

Gorvers, M. J. A. \& Van der Meer, R. (1993). Effects of dietary calcium and phosphate on the intestinal interactions between calcium, phosphate, fatty acids, and bile acids. Gut 34, 365-370.

Gutmann, I. \& Wahlefeld, A. W. (1974). Lactic acid determination. In Methods of Enzymatic Analysis, pp. 1464-1468 [H. U. Bergmeyer, editor]. New York: Academic Press.

Hardwick, L. L., Jones, M. R., Brautbar, N. \& Lee, D. B. N. (1990). Site and mechanism of intestinal magnesium absorption. Minerals \& Electrolytes Metabolism 16, 174-180.

Hylander, E., Ladefoged, K. \& Janum, S. (1980). The importance of the colon in calcium absorption following small-intestinal resection. Scandinavian Journal of Gastroenterology 15, 55-60.

Karbach, U. \& Rummel, W. (1990). Cellular and paracellular magnesium transport across the terminal ileum of the rat and its interaction with the calcium transport. Gastroenterology 98, 985-992.

Kruh, J. (1982). Effects of sodium butyrate, a new pharmacological agent, on cells in culture. Molecular \& Cellular Biochemistry 42, 65 82 .

Lapré, J. A., De Vries, H. T. \& Van der Meer, R. (1991). Dietary calcium phosphate inhibits cytotoxicity of fecal water. American Journal of Physiology 261, G907-912.

Levrat, M.-A., Remesy, C. \& Demigné, C. (1991a). High propionic acid fermentations and mineral accumulation in the caecum of rats adapted to different levels of inulin. Journal of Nutrition 121, 1730-1737.

Levrat, M.-A., Remesy, C. \& Demigné, C. (1991 b). Very acidic fermentations in the rat caecum during adaptation to a diet rich in amylase-resistant starch (crude potato starch). Journal of Nutritional Biochemistry 2, 31-36.

Lipkin, M. (1991). Application of intermediate biomarkers to studies of cancer prevention in the gastrointestinal tract: introduction and perspective. American Journal of Clinical Nutrition 54, 918-928.

Lupton, J. R. \& Kurtz, P. P. (1993). Relationship of colonic luminal short-chain fatty acids and pH to in vivo cell proliferation in rats. Journal of Nutrition 123, 1522-1530.

Lutz, T. \& Scharrer, E. (1991). Effect of short-chain fatty acids on calcium absorption in the rat colon. Experimental Physiology 76, 615-618.

Lutz, T., Wurmli, R. \& Scharrer, E. (1991). Short-chain fatty acids stimulate magnesium absorption by the colon. In Magnesium - A Relevant Ion, pp. 131-137 [B. Lasserre and J. Durlach, editors]. London: John Libbey.

McFarlane, G. T. \& Cummings, J. H. (1991). The colonic flora, fermentation, and large bowel digestive function. In The Large Intestine: Physiology, Pathophysiology and Disease, pp. 51-93 [S. F. Phillips, J. H. Pemberton and R. J. Shorter, editors]. New York: Raven Press.

Morand, C., Rémésy, C., Levrat, M.-A. \& Demigne, C. (1992). Replacement of digestible wheat starch by resistant corn starch alters splanchnic metabolism in rats. Journal of Nutrition 122, 345-354.

Nellans, H. N. \& Goldsmith, R. S. (1981). Transepithelial calcium transport by rat caecum: high efficiency absorptive site. American Journal of Physiology 240, G424-G531.

Olesen, M., Rumessen, J. J. \& Gudman-Høyer, E. (1994). Intestinal transport and fermentation of resistant starch evaluated by the hydrogen breath test. European Journal of Clinical Nutrition 48, 692-701.

Petith, M. M. \& Schedl, H. P. (1976). Intestinal adaptation to dietary calcium restriction: in vivo cecal and colonic calcium transport in the rat. Gastroenterology 71, 1039-1042.

Rayssiguier, Y. \& Rémésy, C. (1977). Magnesium absorption in the caecum of rats related to volatile fatty acid production. Annales de la Recherche Vétérinaire 8, 105-110.

Rechkemmer, G., Ronnau, K. \& Von Engelhardt, W. (1988). Fermentation of polysaccharides and absorption of short chain fatty acids in the mammalian hindgut. Comparative Biochemistry \& Physiology 90A, 563-568.

Rémésy, C., Behr, S. R., Levrat, M.-A. \& Demigné, C. (1992). Fiber fermentability in the rat caecum and its physiological consequences. Nutrition Research 12, $1235-1244$.

Rémésy, C., Levrat, M.-A., Gamet, L. \& Demigné, C. (1993). Caecal fermentations in rats fed oligosaccharides (inulin) are modulated by dietary calcium level. American Journal of Physiology 264, G855-862.

Rheinhold, J. G., Fardji, B. \& Ismail-Beigi, F. (1976). Decreased absorption of calcium, magnesium, zinc and phosphorus by humans due to increased fibre and phosphorus consumption as wheat bran. Journal of Nutrition 106, 493-503.

Scharrer, E. \& Lutz, T. (1992). Relationship between volatile fatty acids and magnesium absorption in mono- and polygastric species. Magnesium Research 5, 53-60.

Schulz, A. G. M., Van Amelsvoort, J. M. M. \& Beynen, A. C. (1993). Dietary native resistant starch but not retrograded resistant starch raises magnesium and calcium absorption in rats. Journal of Nutrition 123, 1724-1731.

Snedecor, G. W. \& Cochran, W. G. (1989). Statistical Methods, 8th ed. Ames: Iowa State University Press.

Trinidad, P. T., Wolever, T. M. S \& Thompson, L. U. (1993). Interactive effects of calcium and short chain fatty acids on absorption in the distal colon of man. Nutrition Research 13, 417-425.

Wargovich, M. J., Eng, V. W. S. \& Newmark, H. L. (1983). Calcium ameliorates the toxic effect of deoxycholic on colonic epithelium. Carcinogenesis 4, 1205-1207.

Würsch, P. (1989). Starch in human nutrition. In Nutritional Values of Cereal Products, Beans and Starches, pp. 199-256 [G. H. Bourne editor]. Basel: Karger. 